152 Literatura e Sociedade

\title{
0 REALISMO SOCIALISTA E SUAS (IN)DEFINIÇÕES
}

Homero FretTas de Andrade

Universidade de São Paulo

Resumo

A partir de um breve panorama das vanguardas literárias russas e soviéticas das duas primeiras décadas do século XX, são tratadas neste ensaio questões relativas a formação, instauração, desdobramentos e produção do assim chamado realismo socialista, que vigorou na URSS de 1932 em diante. Também são estudadas as raízes desse pretenso método de representação artística na tradição literária e crítica russa do século XIX.

Abstract

Starting from a brief view of the russian and soviet literary vanguards of the two first decades of the 20th century, this essay is going to discuss questions concerning the formation, instauration, developments and production of the so-called socialist realism, which was in force in the USSR from 1932 onwards. Also, the roots of that alleged method of artistic representation in the russian literary and critical tradition of the 20th century are here studied.

\author{
Palavras-chave \\ Realismo \\ socialista; \\ realismo crítico; \\ vanguardas \\ russas e \\ soviéticas; \\ literatura \\ soviética; \\ escritores \\ soviéticos.
Keywords
Socialist
realism; critical
realism; Russian
and Soviet
vanguards;
Soviet literature;
Soviet writers.


"A verdadeira literatura não é aquela produzida pelos bem pensantes e zelosos funcionários, mas pelos loucos, eremitas, sonhadores, rebeldes e céticos."

(E. Zamiátin)

"Peço ao Governo Soviético levar em consideração que não sou um político, mas um escritor..."

(M. Bulgákov)

"Eu inventei um novo gênero: o gênero do silêncio."

(I. Bábel)

\section{Q}

uase vinte anos após o esfacelamento da União das Repúblicas Socialistas Soviéticas (URSS), algumas questões se impõem ao estudioso da literatura russa que pretenda examinar a literatura produzida nesse período (1917-1991). A primeira delas, inevitavelmente, diz respeito ao caráter literário dessa produção, ou seja, a literatura soviética preenche os requisitos necessários para ser classificada como "literatura artística" ("khudójestvennaia literatura")? A segunda passa pelos elos entre a literatura russa praticada antes e depois do advento do período soviético. Outras referem-se aos métodos de representação artística utilizados, às eventuais contribuições da literatura soviética ao processo de evolução da língua literária russa, à renovação dos gêneros e formas, e assim por diante. Não se pretende aqui responder pontualmente a essas questões, mas apenas apresentar um breve quadro das principais tendências literárias da década de 1920, além de um esboço da origem, da formação e do desenvolvimento do assim chamado realismo socialista, que possibilitem ao leitor refletir sobre elas.

Costuma-se dizer que a literatura e as artes gozavam de mais liberdade nos tempos de Lenin. ${ }^{1}$ Isso é verdade, mas não significa absolutamente que ambas estivessem fora dos planos de controle do governo bolchevique. Muito pelo contrário: o próprio Lenin, numa série de artigos e ensaios sobre literatura, escritos antes da revolução de Outubro, sempre defendeu a ideia do espírito de partido

\footnotetext{
${ }^{1} \mathrm{Na}$ URSS, a literatura sempre esteve sob o controle do Partido; o que variava era o maior ou menor rigor desse controle. Assim, após o controle absoluto do período de Stalin e em nome do processo de desestalinização do Estado soviético, conhecido como "degelo", houve um relaxamento do controle, que permitiu, inclusive, a reabilitação de alguns dos muitos escritores banidos pelo stalinismo e o aparecimento de obras, cuja publicação seria impensável no período imediatamente anterior. Depois de Khruchtchov ocorreu um novo fechamento que perdurou até o advento da glasnost em 1985. Vale lembrar que, de meados da década de 1950 em diante, obras proibidas ou francamente antissoviéticas foram publicadas e distribuídas de forma clandestina pelo samizdat.
} 
(partíinost) como elemento essencial do processo de criação artística. Para ele, "a arte pertence ao povo. Com suas raízes, ela deve penetrar profundamente nas massas trabalhadoras... Ela deve unir os sentimentos, os pensamentos e a vontade dessas massas, deve exaltá-las". ${ }^{2}$ E prosseguia: "nós não devemos ficar de braços cruzados e deixar o caos se desenvolver livremente. Devemos dirigir metodicamente esse processo e formar seus resultados". ${ }^{3}$ Ou seja, a necessidade de intervir no desenvolvimento da vida literária, impondo uma orientação ideológica aos escritores, decorria justamente dessa concepção que tornava indissolúveis espírito de partido e criação literária em prol da educação socialista do proletariado.

Ainda em 1917, o filósofo marxista A. Bogdánov e o futuro comissário da instrução A. Lunatchárski fundaram os Proletkult (organizações de cultura e educação proletárias) cujo projeto principal era a implementação de uma literatura e de uma arte proletárias. Agrupava escritores e artistas ditos proletários, a maioria deles com escassa formação escolar e intelectual, e promovia debates, espetáculos, além de editar um grande número de jornais e revistas. A posição do Proletkult em relação à literatura anterior a Outubro era ambígua: os membros mais açodados pretendiam a literal abolição do passado burguês e tsarista, condenavam todas as vanguardas literárias e artísticas russas que configuravam o modernismo; Bogdánov, Lunatchárski e outros teóricos, ao contrário, achavam que a arte do passado podia tornar-se patrimônio da nova sociedade, desde que submetida a uma reavaliação de caráter marxista. De todo modo, a Lenin não agradava o fato de uma associação não atrelada ao Partido querer ditar as regras da política cultural a ser implementada e insistia para que ela se subordinasse ao comissariado da instrução pública. Trótski, por sua vez, opunha-se ao projeto, alegando que não existia uma literatura da classe proletária e que não haveria tempo de edificá-la antes do estabelecimento da sociedade sem classes. A oposição ferrenha de ambos enfraqueceu bastante a possibilidade de atuação efetiva do Proletkult, mas não impediu que seus membros se manifestassem com estardalhaço na imprensa, atacando a reputação dos artistas não engajados no movimento.

Então, não controlar com mão de ferro a produção literária no início fez parte eventualmente de uma estratégia, como a que levou Lenin a implantar a Nova Política Econômica (NEP), para reconstruir a economia do país e restabelecer a normalidade da vida cotidiana logo após o término da guerra civil (1918-1921) e da fase do "comunismo de guerra". Em seu Literatura e revolução (1924), Trotski, cujas ideias a respeito do assunto não eram diferentes das de Lenin, após discorrer sobre a arte anterior à revolução do ponto de vista do materialismo dialético, faz uma avaliação dos escritores não engajados que restaram na Rússia depois da debandada daqueles que apoiavam os Brancos e o exílio voluntário ou não dos que não compactuavam com os Vermelhos. "Entre a arte burguesa, que agoniza em

\footnotetext{
${ }^{2}$ Cf. V. Lenin, "O literature i iskusstve" [Sobre a literatura e a arte], in Sobránie Sotchiniénii, Moscou, Naúka, 1979, v. 5, p. 264.

${ }^{3}$ Idem, ibidem, p. 263

${ }^{4}$ Esses escritores formaram nichos em Berlim, Praga e Paris, criando a assim chamada literatura russa da emigração, com editoras e revistas literárias para a divulgação de suas obras. Com exceção
} 
repetições ou em silêncios" - definia ele - "e a nova arte, que ainda não nasceu, criou-se uma arte de transição, que mais ou menos organicamente se liga à revolução, embora não represente a arte da revolução". ${ }^{5}$ Os escritores da transição artística não tinham passado pré-revolucionário, mas tinham tido sua fisionomia literária e intelectual formada pela revolução, "segundo o ângulo pelo qual os tocou. E todos eles a aceitaram, cada um à sua maneira. Mas, na aceitação individual, acha-se um traço comum, que os separa, nitidamente, do comunismo e sempre ameaça voltá-los contra o seu sistema". ${ }^{6}$

Na verdade, de uma única cajadada, Trótski pretendia matar vários problemas: diminuir o poder de fogo dos Proletkult, resolver a situação desses escritores no que se refere à inserção e participação deles na nova sociedade e, ao mesmo tempo, preencher os esvaziados quadros da nascente literatura soviética. Chamou-os popúttchiki (companheiros de viagem) e, no decorrer da década de 1920, a essa categoria de contornos indefinidos foram se juntando escritores que não militavam nas organizações proletárias ou partidárias, embora colaborassem em revistas e suplementos literários ligados a operários e camponeses, como é o caso de alguns dos "Irmãos de Serapião". ${ }^{7}$

A missão dos popúttchiki, entre eles escritores que já publicavam antes da revolução, era produzir obras capazes de funcionar como modelos artísticos para as novas gerações, recuperando o padrão de excelência atingido anteriormente pela literatura russa. Como se vê, essas iniciativas visavam não só ao cumprimento de metas relativas à educação e formação do homem soviético, mas, numa época em que os dirigentes ainda tinham a esperança de se internacionalizar a revolução, também visavam à propaganda do regime fora das fronteiras soviéticas. Afinal, independentemente das repercussões da revolução no resto do mundo, desde o boom de traduções de obras russas em países europeus a partir de 1880, a literatura vinha funcionando como uma espécie de cartão de visita da Rússia.

As obras escritas pelos companheiros de viagem constituíram o tesouro literário da década de 1920 e, certamente, a melhor produção de toda a literatura russosoviética, quer pela alta qualidade artística da maioria dos textos, quer pelo caráter

do que se publicava na revista e na editora Nakanúnie (Às Vésperas), de Berlim, a produção dos emigrados não entrava na URSS a não ser clandestinamente.

${ }^{5}$ Cf. L. Trotski, "Os companheiros de viagem literários da Revolução", in Literatura e revolução, trad. M. Bandeira, Rio de Janeiro, Zahar, 1969, p. 56.

${ }^{6}$ Idem, ibidem, p. 57.

${ }^{7}$ Durante a década de 1920 foram considerados companheiros de viagem Iu. Oliecha, B. Pilniak, M. Bulgákov, I. Bábel, A. Tolstói, B. Pasternak, N. Assiéiev, I. Erenburg, V. Katáiev, M. Chaguinian, O. Forch, V. Lídin, B. Lavreniov, M. Leónov, P. Románov, L. Seifúlina. Já o grupo dos "Irmãos de Serapião", formado em 1921, cujo nome alude à personagem do eremita homônimo de Hoffmann, era composto por prosadores, poetas e críticos que não pretendiam criar uma nova escola, mas pregavam sobretudo a liberdade individual de criação. Entre seus membros, destacaram-se: E. Zamiátin, M. Zóchtchenko, K. Fiédin, V. Kaviérin, V. Chklóvski, I. Gruzdiov, V. Ivánov, L. Lunts, N. Tíkhonov, V. Pozner, M. Slonímski, N. Nikítin, E. Polónskaia. O grupo dissolveu-se em 1929 e a maioria desses escritores continuou a produzir depois disso. 
inovador das formas narrativas, poéticas e dramáticas. Como não constituíssem uma escola, suas contribuições para a formação da literatura soviética tendem a ser avaliadas individualmente. Provavelmente, o único traço que tinham em comum quanto ao fazer poético era sua ligação com a tradição literária russa, à qual davam continuidade, renovando-a com os procedimentos experimentados pelas vanguardas modernistas. Nesse sentido, deram novo alento ao feuilleton, à prosa humorística, criaram a narrativa antiutopia, a sátira de ficção científica.

A par disso, as experimentações de vanguarda iniciadas a partir de 1910 continuavam a se desenvolver, agora de acordo com as exigências dos novos tempos. Os neoclássicos acmeístas $\mathrm{O}$. Mandelstam e A. Akhmátova incorporavam à sua poesia elementos de outras tendências de vanguarda. Dado seu caráter revolucionário, a arte de vanguarda de raízes futuristas tinha pretensões de se tornar arte oficial do regime. O construtivismo, movimento de cunho marxista iniciado em Moscou em 1919, retomava as propostas mais radicais desenvolvidas durante o futurismo e propunha uma arte inserida no cotidiano, inspirada na máquina e na industrialização a serviço da construção do mundo socialista. ${ }^{8}$

O cubo-futurista Maiakóvski criava versos e desenhos para campanhas publicitárias de saneamento básico e fundava o Fronte Esquerdo das Artes (LEF) em 1923, que durou até 1925, com a publicação do sétimo número de sua revista. "Nossas armas são o exemplo, a agitação, a propaganda" - escrevia ele, reafirmando propostas estéticas do primeiro manifesto do cubo-futurismo, "Bofetada no gosto público" (1912) e insistindo na reelaboração dessas propostas em prol da arte soviética. ${ }^{9}$ Em "Como fazer versos" (1926), ensaio teórico em que sintetizou sua concepção poética, Maiakóvski ressaltava a importância do quesito "encargo social" como elemento intrínseco ao processo da criação literária. ${ }^{10}$

\footnotetext{
${ }^{8}$ Esse movimento, que contava com artistas como Maliévitch, Ródtchenko, Tátlin, El Lissítski e outros, obteve resultados mais significativos nas artes plásticas e na arquitetura. Também o cineasta S. Eisenstein sofreu influências do movimento. Em 1920, os irmãos Gabo e Pevsner provocam uma cisão no movimento, afixando em plena guerra civil cartazes com seu "Manifesto do Realismo" por toda Moscou. Para eles, a arte não era mais representação ou configuração geométrica do mundo, mas objeto com função utilitária.

${ }^{9}$ Cf. V. Maiakóvski, "Em quem finca seus dentes a LEF?", in B, Schnaiderman, A poética de Maiakóvski através de sua prosa, trad. B. Schnaiderman, São Paulo, Perspectiva, 1971, p. 225-228. Nele, o estudioso examina a trajetória e as concepções poéticas de Maiakóvski desde o cubo-futurismo até a morte do poeta em 1930. O manifesto citado encontra-se traduzido às p. 70-71. Ainda no mesmo volume, cf. os textos "Carta Aberta aos operários" de 1918 (p. 119-122) e "Agitação e publicidade" de 1923 (p. 127-130). Por meio desses e de outros textos traduzidos e analisados é possível perceber o crescente engajamento do escritor nas palavras de ordem da política cultural soviética.

${ }^{10}$ Cf. B. Schnaiderman, A poética de Maiakóvski através de sua prosa, op. cit., p. 167-220. "Do meu ponto de vista, a melhor obra poética será aquela escrita segundo o encargo social do Komintern, que tenha como objetivo a alcançar a vitória do proletariado, redigida com palavras novas, expressivas e compreensíveis a todos" (p. 175). E mais adiante: "Para compreender corretamente o encargo social, o poeta deve estar no centro dos acontecimentos e trabalhos. [...] Para o cumprimento mais adequado do encargo social, é preciso estar na dianteira de sua classe e com esta conduzir uma luta em todas as frentes. É preciso liquidar de vez com a balela da arte apolítica” (p. 201).
} 
Entretanto, o ressurgimento do realismo na URSS deveu-se em boa parte a imposições de caráter ideológico e a pressões sociais decorrentes de um novo público leitor procedente de extratos inferiores da sociedade soviética que, assim como preferia a arte figurativa, gostava de narrativas e poemas que descrevessem a vida tal como ela era. Lenin e a maioria dos dirigentes do Partido eram partidários do realismo por razões ideológicas e de gosto pessoal, mas também acreditavam que as massas se afastavam instintivamente dos modernistas sofisticados.

Ainda na década de 1920, ao lado da experimentação modernista dos popúttchiki, da vanguarda construtivista e dos oberiúty, ${ }^{11}$ criadores da literatura do absurdo, havia toda uma corrente de escritores (ditos proletários e comunistas) que produzia literatura de caráter realista. Produziam a denominada literatura do fato real (literatura fakta). ${ }^{12} \mathrm{Na}$ maior parte das vezes eram escritores que, no dizer de Slonin, "davam pouca ou nenhuma atenção à forma e às sutilezas da arte", limitando-se ao que julgavam ser "uma representação fiel da realidade". ${ }^{13}$ Ora produziam contos e romances nos moldes de Tchernichévski, usando a realidade factual como pano de fundo de um enredo simples que se prestava como veículo ao proselitismo partidário, ora publicavam ótcherki (forma narrativa misto de reportagem de jornal e ensaio), cujo propósito propagandístico era "a reprodução exata e fiel das pessoas e das condições de trabalho, destacando as conquistas industriais, agrícolas, militares e outras, da vida econômica e social do país". ${ }^{14}$

O grupo "Pierieval" (Passagem), por sua vez, organizado em torno da revista Krásnaia Nov (Terra virgem vermelha), reunia escritores e poetas de formação marxista, alguns dos quais militavam no Partido ou no Komsomol (União da Juventude Comunista). ${ }^{15}$ Com base no pensamento do crítico literário oitocentista V. Belínski e do teórico marxista G. Plekhánov, propunham o "realismo orgânico", acreditavam no poder cognitivo da arte e na intuição do artista. Para eles o realismo era o único estilo natural da nova classe: achavam que a revolução não precisava do que chamavam hiperbolismo de Maiakóvski nem do esquematismo doutrinário dos escritores ligados ao Proletkult.

De acordo com Plekhánov,

o artista expressa seus pensamentos por meio de imagens, enquanto o publicista comprova suas idéias com argumentos lógicos. Se um escritor emprega argumentos lógicos em lugar de imagens, ou se as imagens que criou servem-lhe para demonstrar tal ou qual assunto, não se trata

${ }^{11}$ Membros da Sociedade da Arte Real (Obediniénie Reálnogo Iskússtva), grupo surgido em Leningrado em meados de 1927, liderado por D. Kharms e A. Vvediénski.

${ }^{12} \mathrm{O}$ mais bem sucedido escritor dessa tendência foi, sem dúvida, Isaak Bábel, que em seu $O$ Exército de Cavalaria (1926) soube aliar os procedimentos da literatura fakta com a prosa ornamental que então se praticava.

${ }^{13}$ Cf. M. Slonin, Escritores y problemas de la literatura soviética 1917-1967, trad. A. Bernárdez, Madri, Alianza Editorial, s. d. p. 204

${ }^{14}$ Idem, ibidem, p. 205.

${ }^{15}$ Entre eles E. Bagrítski, I. Katáiev, M. Príchvin e A. Liéjniev. 
de um artista, mas de um publicista, mesmo que escreva, em vez de ensaios e artigos, romances, novelas ou peças de teatro. ${ }^{16}$

Portanto, ao considerar a agitação, a propaganda, o doutrinamento como matérias próprias da publicística e não da literatura artística, o grupo contrariava o pressuposto leninista do espírito de partido em arte.

Mas não era o que acontecia com os escritores e críticos filiados à Associação Russa de Escritores Proletários (RAPP), surgida em 1928, que promulgavam o programa da organização como a linha oficial em literatura. Porta-voz do grupo, o crítico L. Averbakh disparava chumbo grosso contra os popúttchki em geral, que definia como "neoburgueses" e "inimigos da classe", contra os desdobramentos das vanguardas do início do século, os "Irmãos de Serapião", o grupo "Pierieval", e toda literatura não proletária e não comunista, em verdadeiros atos de assassínio de reputação. ${ }^{17}$

O reinado da RAPP, ressalta Slonin,

foi um dos períodos mais lúgubres das letras soviéticas. A política extremista aplicou-se com um fanatismo impiedoso durante três anos, provocando não só muitos incidentes penosos, como também uma campanha difamatória contra os companheiros de viagem [...]. As obras literárias eram avaliadas em função de sua intenção ideológica e política. Imprimiam-se tiragens de romances e versos apressados, mal escritos, pobremente compostos, e por vezes obras de analfabetos, simplesmente porque os autores faziam suas personagens falarem como pediam Averbakh e seus seguidores. No melhor dos casos, as obras aclamadas por seu "puro espírito comunista" eram simplesmente uma regressão aos primeiros tempos do naturalismo ou aos escritores populistas de segunda categoria da década de $1870 .^{18}$

Nos anos de 1928-1932, durante a vigência do primeiro Plano Quinquenal, visando à industrialização em larga escala e à transformação da economia rural, as artes e sobretudo a literatura foram enquadradas pelo partido, com o auxílio encarniçado da RAPP. Deviam representar as conquistas previstas no plano e reforçar a crença de que o socialismo podia ser construído em um único país, como Stalin acabara de formular ao anunciar o fim da NEP e o início de uma etapa decisiva para o estabelecimento da pátria socialista.

De 1929 a 1931 deu-se a coletivização rural forçada, com a criação dos kolkhozes e sovkhozes (fazendas coletivas). No final desse Plano, a um preço exorbitante em vidas e energia do povo, a URSS tinha sofrido uma transformação significativa: as bases da economia tinham se tornado coletivistas, os últimos resquícios de capitalismo foram varridos, os inimigos do proletariado foram liquidados. Estado e Partido controlavam os quatro cantos do mundo soviético. Nesse período, mais do que nunca, escritores e artistas eram convocados a participar dos esforços,

${ }^{16}$ Cf. G. Plekhánov, A arte e a vida social, trad. E. Sucupira, São Paulo, Brasiliense, 1964, p. 26.

${ }^{17}$ Herman Ermolaev, Soviet Literary Theories 1917-1937: The Genesis of Socialist Realism, London, Octagon Books, 1977, apresenta uma pesquisa minuciosa sobre os debates literários e filosóficos da década de 1920, que precederam a formulação do realismo socialista.

${ }^{18}$ M. Slonin, Escritores y problemas de la literatura soviética 1917-1967, op. cit., p. 195. 
formando caravanas para visitas às fazendas coletivas, às fábricas, usinas e outras megaconstruções, com o objetivo de apr(e)ender a realidade do recém-gerado homo sovieticus e promovê-la.

Do ponto de vista artístico, esses esforços geralmente apresentavam resultados pífios. Contemplavam as exigências partidárias de propaganda e doutrinamento, eram obras de publicística, não de literatura. E quando tentavam sê-lo, não transcendiam a representação fotográfica dos fatos, não traziam nenhum aporte crítico, faziam apologia dos slogans do Partido: tudo conforme o receituário defendido por Averbakh. Ao mesmo tempo, diante realidade da nova vida social, a prosa e a poesia comunistas iam se formando organicamente e um grupo considerável de popúttchiki parecia disposto a dar seu apoio ao regime, ${ }^{19}$ mas talvez não com a urgência e a incondicionalidade exigidas pelo comando central do Partido.

Em 23 de abril de 1932, o Comitê Central do Partido tomou a decisão histórica de dissolver todas as associações literárias (proletárias ou não) e fundou a União dos Escritores Soviéticos. Foi o golpe de misericórdia no que restava de liberdade de criação artística na URSS. Tinha início um período negro de totalitarismo no âmbito de todas as manifestações humanas. Górki desempenhou um papel importante nesse contexto de mudança, tendo sido um dos primeiros a comentar a queda de qualidade da literatura produzida a partir de 1929. Secundado por Chólokhov, que em 1928 publicara a primeira parte de seu O Don silencioso, e o escritor da RAPP Fadiéiev, deu início a uma campanha para melhorar o nível artístico da produção literária, que decaíra sensivelmente com a perseguição aos popúttchiki e o início da homogeneização rumo a uma arte socialista. ${ }^{20}$

Com a criação da União, punha-se fim à briga entre os vários grupos literários que disputavam a hegemonia nas letras soviéticas. Mas não só: um único órgão reunindo todos os escritores da URSS permitia ao partido exercer mais facilmente o controle sobre a produção dos "engenheiros da alma humana". Do ponto de vista político, representou "um hábil movimento para a supressão de todo não conformismo e para um controle totalitário da vida cultural e espiritual". ${ }^{21}$

Conforme rezava o estatuto da União, os escritores inscritos deviam obedecer cegamente às orientações do governo soviético, trabalharem para a edificação da pátria socialista e, mais importante e não menos esdrúxulo, criarem segundo o método do realismo socialista. Assim, como sublinha Struve, "um escritor autolimitava o âmbito da sua criatividade nos limites desejados, e aceitava servir ao regime e à sua linha política". ${ }^{22}$ Ainda de acordo com o estatuto, o realismo socialista era o

${ }^{19}$ Idem, ibidem, p. 196.

${ }^{20}$ Nessa mesma época e visando aos mesmos objetivos, Górki participou da criação e da direção do Instituto de Literatura, cuja função era aperfeiçoar a escrita dos jovens escritores e doutriná-los do ponto de vista estético e político.

${ }^{21}$ Cf. G. Struve, Storia della letteratura sovietica, trad. S. Bernardini, Milano, 1977, p. 331.

${ }^{22}$ Idem, ibidem, p. 303. 
método fundamental da literatura e da crítica literária soviética que exige do escritor a descrição verdadeira, historicamente concreta, da realidade vista em seu desenvolvimento revolucionário, e a veracidade e a correção histórica da representação artística da realidade devem acompanhar a tarefa de uma transformação ideal e da educação dos trabalhadores no espírito do socialismo.

Seguiam-se os objetivos quanto à utilização do método: "a criação de obras de elevado nível artístico, marcadas pela heróica luta do proletariado de todo o mundo pela grandiosidade da vitória do socialismo". ${ }^{23}$

Doravante, se uma obra literária fugisse ao espírito do dogma imposto, ela não seria aceita e seu criador arriscava-se a cair em desgraça: "o fator político era decisivo, e embora não se pedisse aos escritores mais do que escreverem romances estritamente industriais ou políticos, eles deviam aderir ao realismo socialista ou preparar-se para o ostracismo". ${ }^{24}$

Porém, desde logo colocou-se a questão: em que consiste a diferença entre realismo socialista e realismo puro e simples? Alguns críticos opunham o realismo socialista ao realismo crítico ou burguês. Afirmavam que o realismo burguês tinha raízes em uma postura crítica, que apresentava uma visão negativa da realidade. Já o realismo socialista, que devia refletir a realidade e a mentalidade socialista, parte "de uma postura positiva em relação à nova realidade de uma sociedade coletivizada. Por isso ele é fundamentalmente otimista, diz sim à vida, ao passo que o velho realismo burguês era fundamentalmente pessimista e implicava frequentemente uma concepção doentia do mundo". ${ }^{25}$

Teóricos e historiadores da matéria, soviéticos e ocidentais, são unânimes em atribuir a M. Górki e à tendência literária da qual ele foi o representante mais significativo a inspiração que deu origem ao realismo socialista. Um dos primeiros escritores russos de extração popular, o socialista Górki renovou em suas obras o conceito de realismo crítico, introduzindo no método elementos de romantismo revolucionário e despindo-o de suas roupagens naturalistas. ${ }^{26}$

Esse método de representação crítica da realidade social russa, teorizado por V. Belínski a partir do exame da produção literária da primeira metade do século XIX, tinha feito escola e dado origem às obras-primas dos grandes escritores da época. Ao mesmo tempo, uma radicalização da perspectiva do realismo crítico, empreendida pela intelligentsia mais extremada a partir de 1860, resultara nas

${ }^{23}$ Cf. Estatuto da União dos Escritores Soviéticos. Estavam previstas ainda obrigações como "participar ativamente com os próprios meios artísticos da construção do socialismo", e penalidades que resultavam na expulsão do membro que contrariassem "os interesses da construção do socialismo ou as finalidades da União", ou que praticassem "ações de caráter antissoviético".

${ }^{24}$ G. Struve, Storia della letteratura sovietica, op. cit., p. 304.

${ }^{25}$ Idem, ibidem, p. 306.

${ }^{26}$ A noção de romantismo revolucionário encontra-se presente nas obras dos escritores de tendência socialista do finalzinho do século XIX e início do XX. Ela se presta, grosso modo, à caracterização idealizada do homem do povo e sua expectativa de uma vida mais justa do ponto de vida social, segundo uma visão de mundo marxista. Diga-se de passagem que a estreia literária de Górki coincidiu com o aparecimento do partido de Lênin na cena política. 
obras dos populistas, que se destacavam por seu caráter utilitário, como veículo para a conscientização social e doutrinação ideológica. ${ }^{27}$ As proposições dessa crítica radical, que fora se tornando predominantemente marxista, passaram para o século seguinte e deram ensejo a trabalhos no campo da filosofia, da ciência política e da publicística. Não que tivessem desaparecido completamente da literatura, mas o surgimento do simbolismo e das vanguardas artísticas do início do século XX reduziu-as a uma das tendências literárias vigentes.

Górki, que participara de reunião com Stalin e a cúpula do Partido para discutir a implantação do novo método de representação do mundo socialista, fez questão de deixar claro, depois disso, que não havia mais lugar para realismo crítico. Declarou ele:

Sem negar o valor do imenso trabalho desenvolvido pelo realismo crítico, e, pelo contrário, valorizando altamente suas conquistas formais, devemos compreender que esse realismo servenos somente para penetrar mais a fundo as remanescências do passado, para combatê-las, para eliminá-las. Mas essa forma de realismo não contribuiu, e não pode contribuir, para educar a personalidade do homem novo, socialista, porque, limitando-se a criticar, não dá nenhum passo à frente e, nos casos piores, retrocede e acaba afirmando o que antes havia negado. ${ }^{28}$

A partir daí consagrou-se uma primeira definição geral de realismo socialista, devidamente inserida no universo do pensamento marxista-leninista. O novo método, também conhecido pela sigla "sotsrealizm" (sotsialistítcheski realizm), devia representar a realidade conjunta, presente e passada, à luz da luta pelo socialismo, e sua característica distintiva devia ser uma mentalidade proletária de partido. Acontece que na ditadura do proletariado era o Partido quem estabelecia totalitariamente as prioridades da "luta pelo socialismo" e forjava a "mentalidade proletária"; portanto, a realidade soviética refletida pelo realismo socialista era deturpada em virtude da propaganda, das táticas e estratégias empregadas para a obtenção dos objetivos estabelecidos. Aliás, o falseamento da própria realidade e dos fatos históricos estavam na ordem do dia, servindo ao culto da personalidade de Stalin, fortalecendo o regime e o Partido. Assim, grosso modo, a realidade em vigor era a decretada pelo Partido e ai de quem ousasse enxergar a realidade de fato. O processo de endeusamento do todo-poderoso pai de todos os proletários do mundo, do deus-vivo, erigia a igreja do stalinismo, guiava corações e mentes, criava mecanismos inquisitoriais de controle da realidade presente, passada e futura, instituindo uma versão atualizada dos tribunais do Santo Ofício. ${ }^{29}$ Esse culto

\footnotetext{
${ }^{27}$ Para uma visão ampla da questão do realismo crítico e da crítica radical, remeto à leitura de I. Berlin, Pensadores russos, São Paulo, Cia das Letras, 1988; e J. Frank, Pelo prisma russo, São Paulo, Edusp, 1992. R. Wellek, História da crítica moderna, São Paulo, Edusp, 1971, faz um apanhado das tendências da crítica literária russa desde o início do século XIX até o início do XX (cf. vv. 3 e 4).

${ }^{28}$ M. Górki, O literature. Statii i riétchi 1928-1936 [Sobre literatura. Artigos e discursos 19281936]. Moscou, Soviétski Pissátel, 1971, p. 471.

${ }^{29}$ Zamiátin, autor do romance antiutopia Nós (1922), onde a possibilidade de falência da nova sociedade é anunciada, costumava comparar o Partido dirigido por Stalin à Igreja católica da época da Inquisição.
} 
à personalidade adquiriu proporções mitológicas e fixou-se como o traço distintivo da sociedade soviética nas décadas de 1930-1940, exercendo sua influência nefasta também na literatura e nas artes.

Em agosto de 1934, no mesmo ano do início dos expurgos stalinistas que culminariam nos famigerados processos de Moscou (1936-1938), realizou-se o I Congresso da União dos Escritores Soviéticos. No discurso de abertura, o portavoz do governo e futuro inquisidor cultural A. Jdánov estabeleceu as tarefas do escritor e as características da literatura:

O nosso escritor extrai o seu material da epopéia heróica dos homens soviéticos, da experiência dos nossos kolkhozes, da atividade criativa que fervilha em cada canto do nosso país. No nosso país os protagonistas das obras literárias são construtores ativos de uma nova vida: operários e operárias, kolkhozianos e kolkhozianas, funcionários do partido, organizadores da economia, engenheiros, jovens do komsomol, pioneiros. Eis os tipos e as personagens fundamentais da literatura soviética. A nossa literatura é pródiga em entusiasmo e heroismo, é otimista [...] É otimista por natureza, enquanto literatura de uma classe em ascensão, o proletariado, única classe progressista e de vanguarda.

E prosseguiu, pontificando sobre a definição e as regras do realismo socialista:

O camarada Stalin denominou nossos escritores engenheiros da alma, O que significa isso? Que obrigações essa definição impõe? Significa, antes de mais nada, conhecer a vida para poder descrevê-la com veracidade nas próprias obras, não de uma maneira escolástica e morta, não simplesmente como uma realidade objetiva, mas como uma realidade colhida em pleno desenvolvimento revolucionário.

O realismo socialista, método básico da literatura e da crítica literária soviéticas, exige do artista uma representação verídica, historicamente concreta da realidade em seu desenvolvimento revolucionário. Ademais a verdade e a integridade histórica da representação artística devem ser acompanhadas pela transformação ideológica e a educação dos trabalhadores no espírito do socialismo. Esse método a ser aplicado à literatura e à crítica literária é o que chamamos método do realismo socialista... ${ }^{30}$

Como se vê pelos trechos escolhidos, toda a ênfase da criação artística recai no conteúdo. Da forma não se fala com clareza, o que permite entender numa certa medida como obras formalmente tão díspares como as escritas nesse período puderam caber atrás do rótulo do realismo socialista. Até mesmo no que se refere aos conteúdos a variação não era grande. Para tratar de temas caros ao Partido como a revolução, a industrialização, a coletivização do campo, usava-se na maioria das vezes um esquema narrativo bem simples: um herói positivo, dotado de uma sólida consciência política e de um enorme espírito de sacrifício, torna-se exemplo para os camaradas não tão dotados assim de como se deve proceder na incansável

${ }^{30}$ Apud G. Struve, Storia della letteratura soviética, op. cit., p. 312-313. No I Congresso manifestaram-se também algumas vozes dissonantes, como as de Oliecha e Pasternak, que foram encobertas pela unanimidade das demais. 
luta para a construção do socialismo. O esquema repetia-se também na poesia e no teatro. ${ }^{31}$

A preocupação com a forma era vista como sinal de decadência, resquícios de mentalidade burguesa. No primeiro número da revista Teatr (1937), afirmava-se com todas as letras no editorial:

O formalismo é o pior inimigo da arte socialista soviética. Seu perigo geralmente reside no fato de que ele oferece aos agentes fascistas, aos desprezíveis degenerados trotskistas, aos renegados de direita e a todos as inimigos do povo a possibilidade de difundir ideias antissoviéticas e contrarrevolucionárias, sob a capa de infinitas maquinações, manobras e "valores estéticos" independentes. ${ }^{32}$

Ora, novos conteúdos devem ensejar novas formas, diz o postulado mais óbvio da criação artística. Mas no caso soviético, o experimentalismo nas artes foi declarado ilegal a partir de 1929, assim como todas as manifestações artísticas de vanguarda. A verdadeira e única arte de vanguarda, agora, era a arte do realismo socialista, cujo método não era um método de representação artística, mas um formulário. A verdadeira e única arte de vanguarda, agora, recorria às formas mais batidas e menos complicadas, por serem mais acessíveis ao grosso dos leitores soviéticos. Não passava pela cabeça dos planejadores da política cultural soviética educar o gosto das massas para que elas pudessem fruir novas formas artísticas, pois as artes, antes de mais nada, deviam servir para doutrinar e controlar o proletariado. No que se refere à teoria e à crítica literária, era o Comitê Central do Partido que determinava suas tarefas: de modo que teóricos e críticos também participavam ativamente da sujeição de autores e obras às orientações partidárias.

Tampouco a aproximação com o Ocidente na II Guerra Mundial modificou esse quadro, pelo contrário as defesas do realismo socialista foram reforçadas contra eventuais influências estrangeiras. A vitória na II Guerra provocou uma nova avalancha de obras de caráter laudatório, em que o herói positivo era mostrado em plena batalha contra o fascismo para salvar a pátria socialista. Sobre os sofrimentos e a penúria do povo, as discriminações, os expurgos, as detenções e execuções, nem uma palavra. Nem uma palavra sobre os gulags, os processos sumários, os fuzilamentos, as penas intermináveis, o terror.

Já em pleno "degelo", com o início do processo de desestalinização das instituições e da vida soviética, houve uma ligeira abertura, com a reabilitação de alguns escritores e obras condenados no período precedente. O realismo socialista

${ }^{31}$ É claro que algumas obras produzidas no período superaram esse esquematismo, graças ao talento de seus autores. Mas certamente não chegaram a ser verdadeiras obras-primas, dadas as limitações impostas. Aliás, quando se desviavam da norma os autores nem sequer tentavam dar seus trabalhos à publicação, para não caírem em desgraça. Um belo levantamento comentado das melhores obras proibidas no período soviético pode ser lido em B. Schnaiderman, Os escombros e o mito, Os escombros e o mito, São Paulo, Companhia das Letras, 1997.

${ }^{32}$ Apud M. slavinski, D. Stolypine, La vie littéraire en U.R.S.S. de 1934 a nos jours, Paris, Stock, 1971, p. 55. 
passou então por um breve questionamento, antes que o tempo fechasse novamente. Assim, num polêmico ensaio escrito em 1957, A. Siniávski ousava pôr em discussão pela primeira vez os cânones literários ditados pelo Partido. ${ }^{33}$ "O que é o realismo socialista?" - indagava ele -

O que significa essa estranha combinação que fere os ouvidos? Por acaso há um realismo socialista, um capitalista, um cristão, um muçulmano? E mais: será que essa noção irracional existe na natureza? Quem sabe não existe? Quem sabe, ela não passe de um sonho, que um intelectual apavorado teve numa noite escura e maléfica da ditadura stalinista? Demagogia grosseira de Jdánov ou esquisitice senil de Górki? Ficção, mito, propaganda?

E não só: ele também questionava se o Partido tinha o direito de imiscuir-se nas artes. Nas cerca de cinquenta páginas do ensaio, usando de ironia e sarcasmo, Siniávski desmontava as noções artísticas do Partido, lançando mão de Marx e Engels, mostrando quão pouco marxistas tinham se tornado as disposições da política cultural e o quanto elas tinham destruído a literatura como tal. Denunciava, além disso, a visão tacanha, utilitária e ideologicamente orientada que os manuais escolares e as obras especializadas apresentavam no que se refere à literatura russa do passado. Recolocava tudo em seus devidos lugares, reivindicando o direito natural do escritor à liberdade de criação. E diante da situação de terra arrasada a que fora reduzida a verdadeira literatura, ele concluía: "Nós não sabemos para onde ir, mas, tendo compreendido que algo deve ser feito, começamos a pensar, a conjeturar, a propor. Quem sabe não inventamos algo surpreendente? Mas isso já não terá mais nada a ver com o realismo socialista".

O texto de Siniávski, publicado no esquema de samizdat, representava as aspirações e expectativas de toda uma nova geração de escritores, que esperavam, sob a égide do "degelo", poder escapar das limitações à criação artística ainda defendidas pela linha dura do Partido. Ledo engano.

Desde o I Congresso dos Escritores Soviéticos em 1934 até o último, já durante a glasnost, ocorreram mudanças de caráter sociopolítico bastante significativas na URSS, em decorrência de acontecimentos ligados ao Grande Expurgo stalinista, à II Grande Guerra, à morte de Stalin, à ascensão e queda de Kruchtchov, ao período de estagnação que se seguiu com Brejniev, Andrópov e Tchernienko, à instituição da perestroika, e o realismo socialista permaneceu em vigor. Em plena glasnost, o historiador da cultura e crítico literário D. Likhatchov, à época ministro

${ }^{33}$ A. Siniávski, "Chto takoie sotsialistítcheski realizm" [O que é o realismo socialista], in Antológuia Samizdata. Disponível em: <http://www.igrunov.ru>. O texto foi publicado no samizdat. O autor, para escapar à censura interna, publicava suas obras no Ocidente sob o pseudônimo de A. Tertz. Menos de dez anos após a publicação desse libelo, Siniávski, juntamente com o poeta e amigo lúli Daniel, que também publicava suas obras no exterior, foi acusado de traição por prática de atividades antissoviéticas (entre elas, publicar livros fora da URSS). O processo marcou época: pela primeira vez acusados declaravam-se não culpados e defendiam em tribunal a ideia de que a literatura não devia ser objeto de julgamento penal, que devia ser independente da política. Cumpriu pena de sete anos de reclusão e depois emigrou, tornando-se professor de literatura russa na Sorbonne. 
de Gorbatchov, responsável pela implementação da perestroika na área cultural, reafirmava: "Nós jamais abandonamos o princípio do caráter de classe da arte, do realismo e da orientação comunista da cultura, das esferas intelectuais e da educação". ${ }^{34}$ O mesmo Likhatchov, num trabalho publicado em 1971, ${ }^{35}$ fez um estudo abrangente do realismo socialista, comparando-o a outras maneiras de representação realista e examinando as teorizações sobre o assunto, produzidas até então no mundo soviético. O fato é que se escreveu muito sobre ele na URSS, uma profusão de livros, tratados, ensaios, teses e artigos, mas nada de novo foi dito.

${ }^{34}$ Soviétskaia Kultura, 7 de julho de 1987, p. 2.

${ }^{35}$ Cf. D. Likhatchov, "Sobre el realismo y su definición", in D. Navarro (org.) Textos y contextos, Havana, Arte y Literatura, 1985, p. 339-418. 